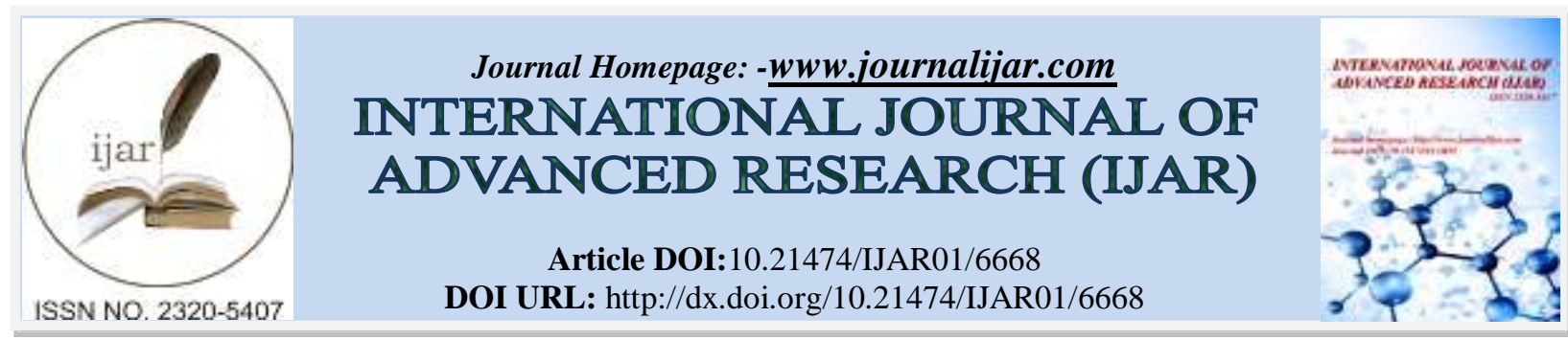

RESEARCH ARTICLE

\title{
A STUDY ON STRADDLE OPTIONS STRATEGY - A GUIDE TO THE EQUITY DERIVATIVES INVESTORS.
}

\author{
Ramasamy. $V^{1}$ and Dr. G. Prabakaran ${ }^{2}$.
}

1. Ph.D Research Scholar, Management, Bharathiar University, Coimbatore, Tamilnadu.

2. Assistant Professor, Government Arts College Dharmapuri, Tamilnadu.

\section{Manuscript Info}

Manuscript History

Received: 04 January 2018

Final Accepted: 06 February 2018

Published: March 2018

Keywords:-

Call \& Put option, Long \& Short

Straddle and Market Participants.

\begin{abstract}
Options are measured risky for investors and speculators due to oscillation in the direction of price movements. An investor has to face the risk of profits where it may be enormously high; here investors fail in deciding profitable options. The study is made to curtail the risk of investors by using Long and Short Straddle option strategy in choosing profitable investment strategy and to know how the option combination strategy would be profitable when market moves up or down. The study has considered the Index of both increasing and decreasing prices, so that it would be probable to give suggestions for investors that how in both cases they can make profits.
\end{abstract}

Copy Right, IJAR, 2018,. All rights reserved.

\section{Introduction:-}

Straddles are a good strategy to pursue if an investor believes that an Index or stock's price will move significantly but is unsure as to which direction. Thus, this is a neutral strategy, as the investor is indifferent whether the stock goes up or down, as long as the price moves enough for the strategy to earn a profit. This strategy are involves two options of same strike prices and same maturity. A long straddle position is created by buying a call and a put option of same strike and same expiry whereas a short straddle is created by shorting a call and a put option of same strike and same expiry.

\section{Straddle Mechanics and Characteristics:-}

The key to creating a long straddle position is to purchase one call option and one put option. Both options must have the same strike price and expiration date. If non-matching strike prices are purchased, the position is then considered to be a strangle, not a straddle.

Long straddle positions have unlimited profit and limited risk. If the price of the underlying asset continues to increase, the potential profit is unlimited. If the price of the underlying asset goes to zero, the profit would be the strike price less the premiums paid for the options. In either case, the maximum risk is the total cost to enter the position, which is the price of the call option plus the price of the put option.

The profit when the price of the underlying asset is increasing is given by:

Profit(up) $=$ Price of the underlying asset - the strike price of the call option - net premium paid

The profit when the price of the underlying asset is decreasing is given by:

Profit $($ down $)=$ Strike price of put option - price of the underlying asset - net premium paid 
The maximum loss is the total net premium paid plus any trade commissions. This loss occurs when the price of the underlying asset equals the strike price of the options at expiration.

There are two breakeven points in a straddle position. The first, known as the upper breakeven point, is equal to strike price of the call option plus the net premium paid. The second, the lower breakeven point, is equal to the strike price of the put option less the premium paid.

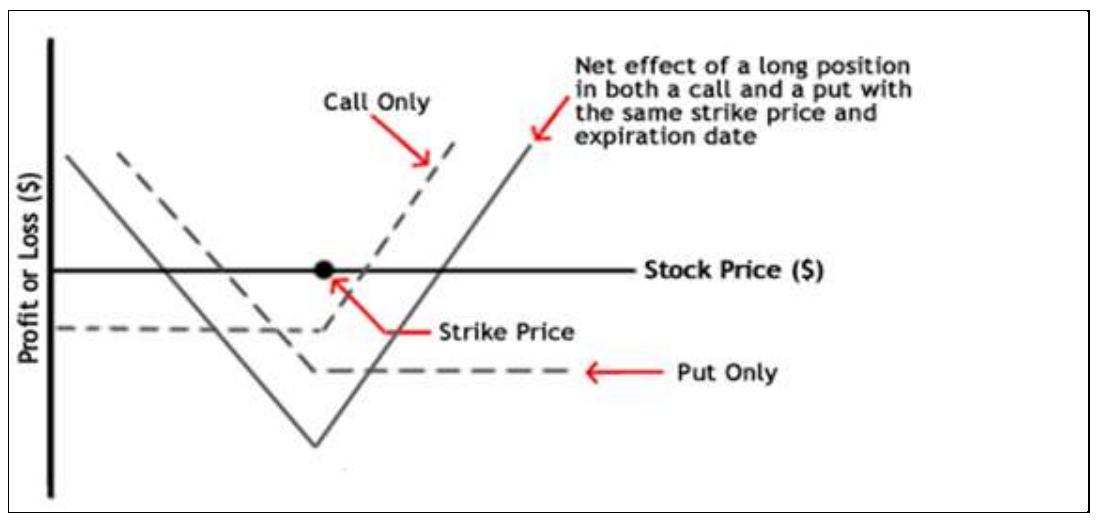

\section{Call option:-}

A call option gives the holder (buyer or the one who long call) the right to buy a specified quantity of the underlying asset at the strike price on or before the expiration date. The seller (the writer or the one who is short call) however, has the obligation to sell the underlying asset if the buyer of the call option decides to exercise his option to buy. In general, a call option will always be exercised at the expiration date if the market price of the underlying assets is above the strike price.

\section{Put option:-}

A put option gives the holder (buyer or the one who long put) the right to sell a specified quantity of the underlying asset at the strike price on or before the expiration date. He may or may not exercise the right. The seller or the writer of the put option has the obligation to buy the underlying asset at the strike price if the buyer decides his option to sell. A put option will be exercised if the exercise price is greater than the current market price of the underlying asset.

Option, which gives buyer a right to buy the underlying asset, is called Call option and the option which gives buyer a right to sell the underlying asset, is called Put option.

\section{Option terminology:-}

There are several terms used in the options market. Let us understand on each of them with the help of the following concept:

Index option: These options have index as the underlying asset. For example options on Nifty, Sensex, etc.

Stock option: These options have individual stocks as the underlying asset. For example, option on ONGC, NTPC etc.

Buyer of an option: The buyer of an option is one who has a right but not the obligation in the contract. For owning this right, he pays a price to the seller of this right called 'option premium' to the option seller.

Writer of an option: The writer of an option is one who receives the option premium and is thereby obliged to sell/buy the asset if the buyer of option exercises his right.

American option: The owner of such option can exercise his right at any time on or before the expiry date/day of the contract.

European option: The owner of such option can exercise his right only on the expiry date/day of the contract. In India, Index options are European.

Lot size: Lot size is the number of units of underlying asset in a contract. Lot size of Nifty option contracts is 183.35. Accordingly, in our examples picture 1, total premium for call option of January 2018 contract would be Rs. $183.35 \times 75=13751.25$ and total premium for put option contract would be Rs. $92.55 \times 75=6941.25$. 
Expiration Day: The day on which a derivative contract ceases to exist. It is the last trading date/day of the contract. In our example, the expiration day of contracts is the last Thursday of September month i.e. 25 January, 2018.

Spot price (S): It is the price at which the underlying asset trades in the spot market. In our examples, it is the value of underlying viz. 10435.55.

Strike price or Exercise price $(\mathbf{X})$ : Strike price is the price per share for which the underlying security may be purchased or sold by the option holder. In our examples, strike price for both call and put options is 10400 .

Open Interest: As discussed in futures section, open interest is the total number of option contracts outstanding for an underlying asset.

\section{Exercise of Options}

In case of American option, buyers can exercise their option any time before the maturity of contract. All these options are exercised with respect to the settlement value/ closing price of the stock on the day of exercise of option.

Picture 1:-Call Option Price of 10400 Strike Price of Jan2018 Contract

\begin{tabular}{|c|c|c|c|c|c|c|c|c|c|c|c|c|c|c|c|c|}
\hline Symbel & Dase & Expiry & $\begin{array}{l}\text { Option } \\
\text { type }\end{array}$ & $\begin{array}{l}\text { Strike } \\
\text { Price }\end{array}$ & Open & Migh & Low. & Clase & LTP & $\begin{array}{l}\text { Settie } \\
\text { Price }\end{array}$ & $\begin{array}{l}\text { No. of } \\
\text { contracts }\end{array}$ & $\begin{array}{l}\text { Turnover " } \\
\text { in \& Lats }\end{array}$ & $\begin{array}{l}\text { Premium } \\
\text { Turnover } \\
\text { in } ₹ \text { Lacs }\end{array}$ & Open Int & $\begin{array}{l}\text { Change } \\
\text { in of }\end{array}$ & $\begin{array}{l}\text { Underlying } \\
\text { Value }\end{array}$ \\
\hline AIFTY & 01. Jan 2018 & $25 . \operatorname{Jan} 2018$ & CF & $10,400,00$ & 220,30 & 223.35 & 175.60 & 183.35 & 178,00 & 133,35 & 10,195 & $81,041,68$ & $1,520,68$ & $11, \pi 3,550$ & 36,375 & $10,035,95$ \\
\hline NIFTY & $02 \cdot \tan 2018$ & 25.Jan-2018 & $\mathcal{C}$ & $10,430.00$ & 193.00 & 198.30 & 149.50 & 167.35 & 163.05 & 167,35 & & $2,89,791.55$ & $4,537,75$ & $15,69,750$ & $1,96,200$ & 10.42 .20 \\
\hline NIFTY & $03 \cdot \tan 2018$ & 25. $\tan 2018$ & CF & $10,420.00$ & 176.70 & 208.35 & 153.65 & 162.60 & 163.00 & 162.60 & 36,803 & $2,91,925,15$ & $4,861,75$ & $16,81,125$ & $1,11,375$ & $10,43.20$ \\
\hline NIFTY: & $04 \cdot \tan 2098$ & $25 . \tan \cdot 2018$ & $C E$ & $10,-200,00$ & 171.10 & 199.75 & 157,85 & 190.70 & 199.00 & 190.70 & 39,213 & $2,11,024,81$ & $5,173,41$ & $18,60,375$ & $1,79,250$ & $10,504,80$ \\
\hline MIFTY & $05 \cdot \tan \cdot 2018$ & 25. $\tan \cdot 2018$ & CE & $10,400.00$ & 201.35 & 226,40 & 196.70 & 220.73 & 225.00 & 220.75 & 16,835 & $1,33,999,50$ & $2,686,50$ & $17,43,675$ & $-1,16,700$ & $10,558.85$ \\
\hline NIFTY & $08 . \tan 2018$ & $25 \cdot \operatorname{san}-2018$ & ce & $10,420,00$ & 248.10 & 269.90 & 241.20 & 263.25 & 259.09 & 263.25 & 13,467 & $1,07,461,06$ & & $14,25,150$ & $-3,18,525$ & $10,623,60$ \\
\hline NIFTY & $09-\tan -2058$ & & CE & & & & & 276.35 & & & & & & & & 10.637 .00 \\
\hline NIrT & $10 \cdot \tan 2018$ & $25 \cdot \tan -2018$ & $\mathbb{C}$ & $10,490,00$ & 270.70 & 274.00 & 233.90 & 283.30 & 262.10 & & 5,022 & & $1,664,40$ & $12,73,750$ & -28.950 & 10.632 .20 \\
\hline NIFFN & 11. $\tan -2018$ & 25-Jan-2018 & $\mathrm{CE}$ & $10,420.00$ & $255 . M$ & 294.85 & 247.30 & $2 \pi 5.00$ & 282.00 & 275.00 & 3,974 & $31,809.88$ & 312.68 & $12,34,125$ & $-39,225$ & $10,651: 20$ \\
\hline MIFTV & 12.500 .2018 & 25 Jan-2018 & 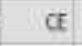 & $10,020,00$ & 305.50 & 307.05 & 20.75 & 299.20 & 299.00 & 299.20 & 6,805 & 54.542 .7 & $1,463.73$ & $11,24,550$ & $-1,09,575$ & $10,081.25$ \\
\hline NIFTY & 15- $\tan -2018$ & 25-Jan-2018 & $C E$ & $10,400,00$ & 326.20 & 377.75 & 325.00 & $35 t .00$ & 350.50 & 351,00 & 3,954 & $31,894,61$ & $1,053,41$ & $10,46,775$ & $-n, 775$ & $10,741,55$ \\
\hline AIFTY & 16. Jan 2018 & $25 \cdot \operatorname{Jan} 2018$ & cF & $10,400.00$ & 357.55 & 360.60 & 301,50 & 315,45 & 326.65 & 315,45 & 2.160 & $17,385,15$ & 537.15 & $10,07,200$ & 39,375 & $10,700,45$ \\
\hline NIFTN & $17 \cdot 5 \operatorname{son}-2018$ & 25-Jan-2018 & $c \varepsilon$ & $10,400.00$ & 308.50 & 407.90 & 278.55 & 390.50 & 397.00 & 390.50 & 2,004 & $16,143,66$ & 512.46 & $9,83,325$ & $-24,075$ & 10.788 .55 \\
\hline NIFTY & $18 \cdot \tan 2018$ & $25 \cdot \tan -2018$ & $c \in$ & $10,400.00$ & 495.30 & $\$ 95.30$ & 377,95 & 406.75 & 409,80 & 408.25 & 1,901 & $15,460.86$ & 633.06 & $9,25,650$ & $-57,575$ & $10,857,00$ \\
\hline NIFTY & 19. $\mathrm{Jan}-2018$ & 25-Jan-2018 & $C E$ & $10,400,00$ & 408.25 & 514,35 & 396.60 & 507.85 & 513.75 & 507.85 & 1,433 & $11,682.82$ & 305.42 & $8,74,350$ & $-51,300$ & $10,894,70$ \\
\hline NIFTY & $22 \tan \cdot 2018$ & $25 \cdot \tan 2018$ & EE & $10,420.00$ & $\operatorname{sis} 20$ & 577.30 & 486.05 & 564.80 & $56+1.80$ & $56+.80$ & 1,855 & $13,187,07$ & 718.07 & $7,91,100$ & 83,250 & $10,966.20$ \\
\hline NIFTY & $23.5 \mathrm{~m} 2018$ & 25.Jan-2018 & CE & $10,420,00$ & 600.50 & 692.85 & 600.50 & 600.85 & 681.25 & 699,85 & 2,006 & $16,629,45$ & 982.65 & $6,94,125$ & $-96,975$ & $11,083.70$ \\
\hline NIFTY & $24 \tan -2018$ & 25-Jan-2018 & ce & 10.420 .00 & 652.20 & 706.00 & 645.00 & 677.75 & 675.00 & 677.75 & 3,521 & 29.261 .76 & $1, \pi 97.96$ & $4,91,700$ & $-2,02,425$ & $11,086,00$ \\
\hline NIFTV & 25. $\tan 2018$ & 25-Jan-2018 & $\boldsymbol{G}$ & $10,420,00$ & 67.25 & 683.05 & 605.10 & 652.65 & 662.00 & 0.00 & 3,803 & $31,525.71$ & $1,862.31$ & $2,73,975$ & $-2,17,725$ & $11,069,65$ \\
\hline
\end{tabular}

The picture 1 and 2 explains the premium of both call and put options of 10400 strike price. The National Stock Exchange is publishing all of the following details for the derivatives contracts being traded on the exchanges.

Date: This gives the Trade date. Symbol: This gives the underlying index of NIFTY,

Instrument: This gives the contract descriptor for the various instruments available in the derivatives segment e.g. OPTIDX. Expiry date: The date on which the contract expires

Option Type: This gives the type of option for the contract. (CE- Call European, PE- Put European)

Strike Price:This gives the Strike Price of the contract.

Opening price: This gives the price at which the contract opened for the day.

High price: This gives the highest price at which the contract was traded during the day. 
Picture 2:-Put Option Price of 10400 Strike Price of Jan2018 Contract

\begin{tabular}{|c|c|c|c|c|c|c|c|c|c|c|c|c|c|c|c|c|}
\hline Symbol & Date & Expiry & $\begin{array}{l}\text { Option } \\
\text { type }\end{array}$ & $\begin{array}{l}\text { Strike } \\
\text { Price }\end{array}$ & Open & High & Low & Close & LTP & $\begin{array}{l}\text { Settle } \\
\text { Price }\end{array}$ & $\begin{array}{l}\text { No. of } \\
\text { contracts }\end{array}$ & $\begin{array}{l}\text { Turnover } \\
\text { in } ₹ \text { Lacs }\end{array}$ & $\begin{array}{l}\text { Premium } \\
\text { Turnover } \\
\text { in } ₹ \text { Lacs }\end{array}$ & Open int & $\begin{array}{l}\text { Change } \\
\text { in } d\end{array}$ & $\begin{array}{l}\text { Underlying } \\
\text { Value }\end{array}$ \\
\hline MFTY & 01-Jan-2018 & 25-Jan-2018 & PE & $10,400.00$ & 80.00 & 96.50 & 74.60 & 92.55 & 95.00 & 92.55 & 75,033 & $5,90,057.99$ & $4,800.59$ & $37,96,575$ & $-1,79,325$ & $10,435.55$ \\
\hline NFTY & 02-Jan-2018 & 25-Jan-2018 & PE & $10,400.00$ & 81.00 & 116.40 & 80.40 & 101.50 & 104.85 & 101.50 & $1,56,511$ & $12,32,857,38$ & $12,081.58$ & $46,07,550$ & $8,10,975$ & $10,442.20$ \\
\hline MFTY & 03-Jan-2018 & 25- $\operatorname{lan}-2018$ & PE & $10,400.00$ & 93.45 & 102.50 & 69.85 & 96.80 & 96.45 & 96.80 & $1,60,202$ & $12,60,147.61$ & $10,572.01$ & $46,96,275$ & 88,725 & $10,443.20$ \\
\hline NFTY & $04-\tan -2018$ & 25- $\tan -2018$ & PE & $10,400.00$ & 89.00 & 100.30 & 69.90 & 73.70 & 69.90 & 73.70 & $1,35,870$ & $10,68,319.25$ & $8,533.25$ & $54,01,800$ & $7,05,525$ & $10,504.80$ \\
\hline NFTY & $05 \cdot \operatorname{Jan} \cdot 2018$ & 25-Jan-2018 & PE & $10,400.00$ & 63.85 & 69.15 & 50.50 & 55.20 & 52.00 & 55.20 & $1,35,940$ & $10,66,445.01$ & $6,073.01$ & $60,85,725$ & $6,83,925$ & $10,558.85$ \\
\hline NFTY & $08-\operatorname{Jan}-2018$ & 25-Jan-2018 & PE & $10,400.00$ & 42.60 & 44.75 & 38.00 & 39.00 & 39.35 & 39.00 & $1,03,441$ & $8,09,961.35$ & $3,121.55$ & $64,47,225$ & $3,61,500$ & $10,623.60$ \\
\hline NFTY & 09. $\tan -2018$ & 25-Jan-2018 & PE & $10,400.00$ & 35.10 & 42.45 & 33.70 & 35.50 & 36.20 & 35.50 & $1,04,100$ & $8,14,940.05$ & $2,960.05$ & $68,35,050$ & $3,87,825$ & $10,637.00$ \\
\hline NFTY & $10-\tan -2018$ & $25-\operatorname{lan}-2018$ & PE & $10,400.00$ & -35.05 & 43.90 & 34.15 & 35.80 & 35.85 & 35.80 & $1,02,334$ & $8,01,161: 02$ & $2,955.82$ & $65,64,900$ & $-2,70,150$ & $10,632.20$ \\
\hline NFTY & 12-Jan-2018 & 25-Jan-2018 & PE & $10,400,00$ & 22.00 & 38.45 & 19.20 & 20.05 & 19.25 & 20.05 & $1,88,356$ & $14,72,789.94$ & $3,613,14$ & $56,68,200$ & $-5,26,650$ & $10,681.25$ \\
\hline MFTY & 15-Jan-2018 & 25-Jan-2018 & PE & $10,400.00$ & 17.55 & 17.55 & 11.80 & 12.65 & 12.35 & 12.65 & $1,02,625$ & $8,01,481.63$ & $1,006.63$ & $55,29,525$ & $-1,38,675$ & $10,741.55$ \\
\hline NFT & 16-Jan-2018 & $25-\tan -2018$ & PE & $10,400.00$ & 11.10 & 14.70 & 10.15 & 12.75 & 11.35 & 12.75 & 91,698 & $7,16,113,65$ & 869.25 & $51,51,525$ & $-3,78,000$ & $10,700,45$ \\
\hline NFTY & 17-Jan-2018 & $25-\operatorname{lan}-2018$ & PE & $10,400.00$ & 12.05 & 16.15 & 6.55 & 7.15 & 6.75 & 7.15 & $1,08,453$ & $8,46,718.17$ & 784.77 & $50,59,950$ & $-91,575$ & $10,788.55$ \\
\hline NFTY & $18-\operatorname{Jan}-2018$ & 25-Jan-2018 & PE & $10,400.00$ & 4.20 & 6.60 & 4.00 & 5.15 & 5.50 & 5.15 & $n 2,440$ & $5,65,294.47$ & 262.47 & $49,19,625$ & $-1,40,325$ & $10,817.00$ \\
\hline NFTY & 19. $\operatorname{Jan}-2018$ & 25-.lan-2018 & PE & $10,400.00$ & 4.25 & 5.15 & 3.25 & 3.50 & 3.60 & 3.50 & 72,842 & $5,68,383.68$ & 216.68 & $46,92,600$ & $-2,27,025$ & $10,894.70$ \\
\hline NFTY & $22 \cdot \tan -2018$ & 25-Jan-2018 & PE & $10,400.00$ & 3.00 & 3.90 & 2.10 & 3.60 & 3.65 & 3.60 & 39,204 & $3,05,892.74$ & 101.54 & $42,22,575$ & $-4,70,025$ & $10,966.20$ \\
\hline NFTY & 23-Jan-2018 & 25-. $\mathrm{lan}-2018$ & PE & $10,400.00$ & 275 & 3.60 & 2.50 & 2.85 & 2.70 & 2.85 & 37,388 & $2,91,708.07$ & 81.67 & $39,53,625$ & $-2,68,950$ & $11,083.70$ \\
\hline NFTY & $24 \tan -2018$ & 25-Jan-2018 & PE & $10,400,00$ & 2.25 & 2.65 & 1.10 & 1.90 & 1.15 & 1.90 & 37,782 & $2,94,756,04$ & 56.44 & $34,72,350$ & $-4,81,275$ & $11,066.00$ \\
\hline
\end{tabular}

Low price: This gives the lowest price at which the contract was traded during the day.

Closing price: This gives the price of the contract at the end of the day.

Last traded price: This gives the price at which the last contract of the day was traded.

Open Interest: For futures contracts open interest is equivalent to the open positions in that futures contract multiplied by its last available closing price. For option contracts, open interest is equivalent to the open positions multiplied by the notional value. Notional value with respect to an option contract is computed as the product of the open position in that option contract multiplied by the last available closing price of the underlying.

Total Traded Quantity: This is the total no. of contracts on which business took place during the day.

Total Traded Value: The total money value of the business which took place on the contract during the day.

Number of Trades: The total no. of trades which took place on the instrument during the day.

Opening a Position:-

An opening transaction is one that adds to, or creates a new trading position. It can be either a purchase or a sale. With respect to an option transaction, we will consider both:

1) Opening purchase (Long on option) - A transaction in which the purchaser's intention is to create or increase a long position in a given series of options.

2) Opening sale (Short on option) - A transaction in which the seller's intention is to create or increase a short position in a given series of options.

3)

Risk and return profile of option contracts

\begin{tabular}{|l|l|l|}
\hline & Risk & Return \\
\hline Long & Premium paid & Unlimited \\
\hline Short & Unlimited & Premium received \\
\hline
\end{tabular}

A long option position has limited risk (premium paid) and unlimited profit potential. A short option position has unlimited downside risk, but limited upside potential (to the extent of premium received) 


\section{In the money, At the money and Out of the money option}

a) In the money (ITM) option:

This option would give holder a positive cash flow, if it were exercised immediately. A call option is said to be ITM, when spot price is higher than strike price. And, a put option is said to be ITM when spot price is lower than strike price.

\section{b) At the money (ATM) option:}

At the money option would lead to zero cash flow if it were exercised immediately. Therefore, for both call and put ATM options, strike price is equal to spot price.

c) Out of the money (OTM) option: Out of the money option is one with strike price worse than the spot price for the holder of option. In other words, this option would give the holder a negative cash flow if it were exercised immediately. A call option is said to be OTM, when spot price is lower than strike price. And a put option is said to be OTM when spot price is higher than strike price.

In summary, if $\mathbf{S}$ is the spot price of the underlying asset and $\mathbf{X}$ is the exercise price:-

$\begin{array}{lll}\text { A call option is } & \text { In the money } & \text { When } S>X \\ & \text { At the money } & \text { When } S=X \\ & \text { Out of the money } & \text { When } S<X \\ \text { A put option is } & \text { In the money } & \text { When } S<X \\ & \text { At the money } & \text { When } S=X \\ & \text { Out of the money } & \text { When } S>X\end{array}$

Option price/Premium: It is the price which the option buyer pays to the option seller. An option premium may also refer to the current price of any specific option contract that has yet to expire.

The components of an option premium include its intrinsic value, its time value and the implied volatility of the underlying asset. As the option nears its expiration date, the time value will edge closer and closer to 0 , while the intrinsic value will closely represent the difference between the underlying security's price and the strike price of the contract.

\section{Straddle}

\section{Long Straddle}

If a person buys both a call and a put at these prices, then his maximum loss will be equal to the sum of these two premiums paid, which is equal to 393. And, price movement from here in either direction would first result in that person recovering his premium and then making profit. This position is undertaken when trader's view on price of the underlying is uncertain but he thinks that in whatever direction the market moves, it would move significantly in that direction.

\section{Pay off Charts for Long Straddle:-}

Chart 1 explainsNifty is trading at Rs 6,000 and premiums for ATM call and put options are 257 and 136 respectively.

Now, let us analyze his position on various market moves. Let us say the stock price falls to 5300 at expiry. Then, his pay offs from position would be:

Long Call: 257 (market price is below strike price, so option expires worthless)

Long Put: $136(5300-6000)=564$

Net Flow: $564-257=307$

As the stock price keeps moving down, loss on long call position is limited to premium paid, whereas profit on long put position keeps increasing.

Now, consider that the Nifty price shoots up to 6700 .

Long Call: $257(6000-6700)=443$

Long Put: 136

Net Flow: $443-136=307$

As the Nifty price keeps moving up, loss on long put position is limited to premium paid, whereas profit on long call position keeps increasing. 
Thus, it can be seen that for huge swings in either direction the strategy yields profits. However, there would be a band within which the position would result into losses. This position would have two Break even points (BEPs) and they would lie at "Strike - Total Premium" and "Strike + Total Premium". Combined pay-off may be shown as follows:

\begin{tabular}{|l|l|l|}
\hline Option & Call & Put \\
\hline Long / Short & Long & Long \\
\hline Strike & 6000 & 6000 \\
\hline Premium & 257 & 136 \\
\hline Spot & 6000 & \multicolumn{1}{|l}{}
\end{tabular}

It may be noted from the picture, that maximum loss of Rs. 393 would occur to the trader if underlying expires at strike of option viz. 6000. Further, as long as underlying expires between 6393 and 5607, he would always incur the loss and that would depend on the level of underlying. His profit would start only after recovery of his total premium of Rs. 393 in either direction and that is the reason there are two breakeven points in this strategy.

Chart 1 Pay off Charts for Long Straddle

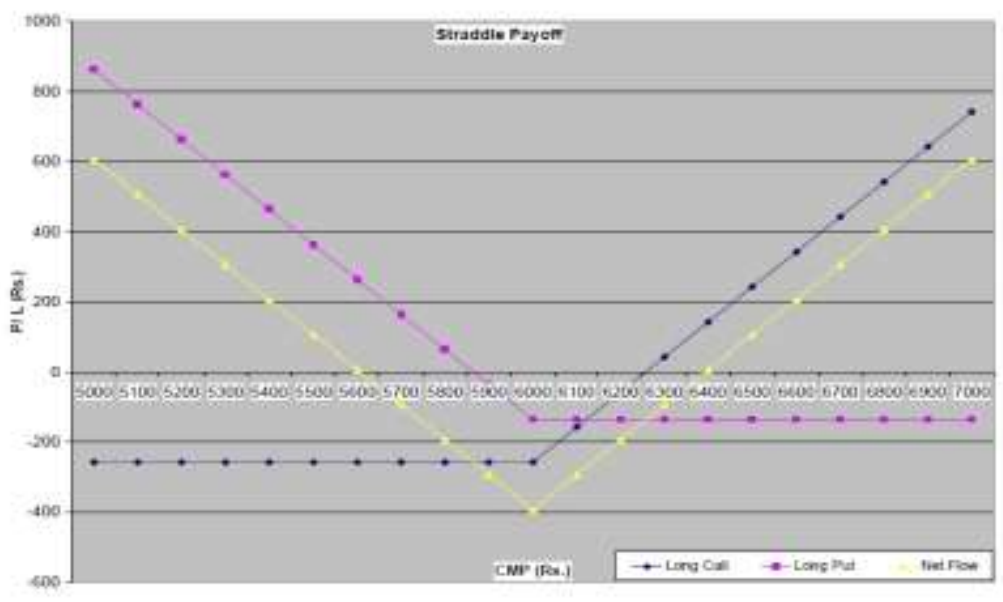

Table.1 At The Money Call and Put option Premium

\begin{tabular}{|c|c|c|c|}
\hline CMP & Long Call & Long Put & Net Flow \\
\hline 5000 & -257 & 864 & 607 \\
\hline 5100 & -257 & 764 & 507 \\
\hline 5200 & -257 & 664 & 407 \\
\hline 5300 & -257 & 564 & 307 \\
\hline 5400 & -257 & 464 & 207 \\
\hline 5500 & -257 & 364 & 107 \\
\hline 5600 & -257 & 264 & 7 \\
\hline 5700 & -257 & 164 & -93 \\
\hline 5800 & -257 & 64 & -193 \\
\hline 5900 & -257 & -36 & -293 \\
\hline 6000 & -257 & -136 & -393 \\
\hline 6100 & -157 & -136 & -293 \\
\hline 6200 & -57 & -136 & -193 \\
\hline 6300 & 43 & -136 & -93 \\
\hline 6400 & 143 & -136 & 7 \\
\hline 6500 & 243 & -136 & 107 \\
\hline 6600 & 343 & -136 & 207 \\
\hline 6700 & 443 & -136 & 307 \\
\hline 6800 & 543 & -136 & 407 \\
\hline 6900 & 643 & -136 & 507 \\
\hline 7000 & 743 & -136 & 607 \\
\hline & & &
\end{tabular}




\section{Short Straddle}

This would be the exact opposite of long straddle. Here, trader's view is that the price of underlying would not move much or remain stable. So, he sells a call and a put so that he can profit from the premiums. As position of short straddle is just opposite of long straddle, the pay off chart would be just inverted, so what was loss for long straddle would become profit for short straddle.

\section{Pay off Charts for Short Straddle}

Position may be shown as follows:

\begin{tabular}{|l|l|l|}
\hline Option & Call & Put \\
\hline Long / Short & Short & Short \\
\hline Strike & 6000 & 6000 \\
\hline Premium & 257 & 136 \\
\hline Spot & 6000 &
\end{tabular}

It should be clear that this strategy is limited profit and unlimited loss strategy and should be undertaken with significant care. Further, it would incur the loss for trader if market moves significantly in either direction - up or down.

\section{Chart 2 Pay off Charts for Short Straddle}

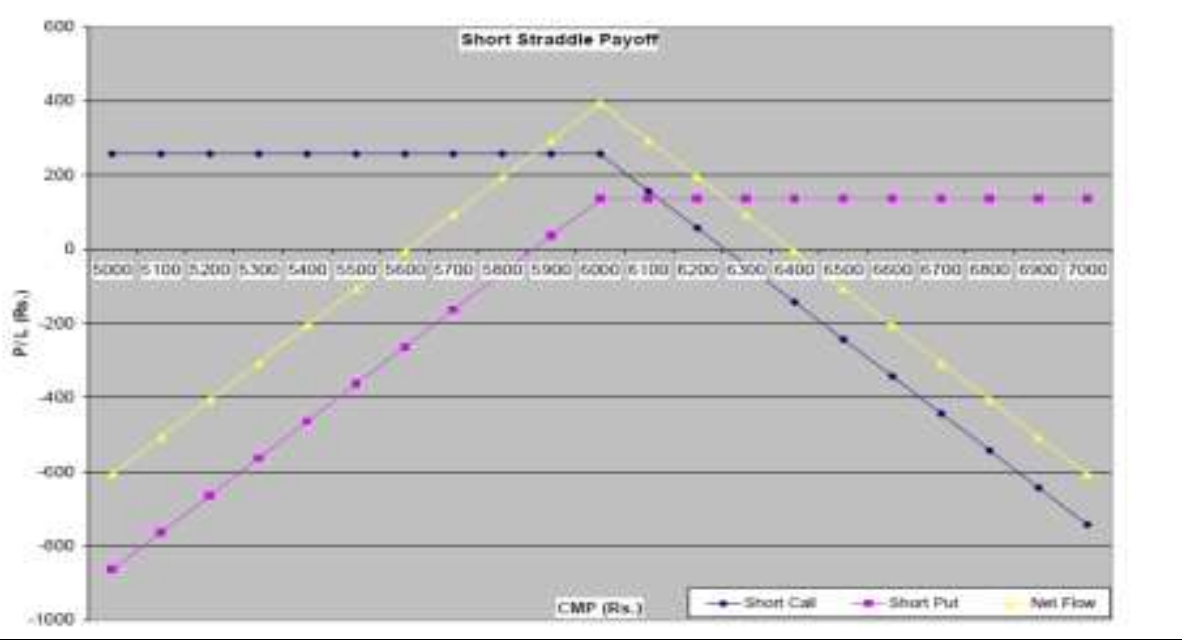

Table. 2 Out of The Money Call and Put option Premium

\begin{tabular}{|c|c|c|c|}
\hline CMP & Short Call & Short Put & Net Flow \\
\hline 5000 & 257 & -864 & -607 \\
\hline 5100 & 257 & -764 & -507 \\
\hline 5200 & 257 & -664 & -407 \\
\hline 5300 & 257 & -564 & -307 \\
\hline 5400 & 257 & -464 & -207 \\
\hline 5500 & 257 & -364 & -107 \\
\hline 5600 & 257 & -264 & -7 \\
\hline 5700 & 257 & -164 & 93 \\
\hline 5800 & 257 & -64 & 193 \\
\hline 5900 & 257 & 36 & 293 \\
\hline 6000 & 257 & 136 & 393 \\
\hline 6100 & 157 & 136 & 293 \\
\hline 6200 & 57 & 136 & 193 \\
\hline 6300 & -43 & 136 & 93 \\
\hline 6400 & -143 & 136 & -7 \\
\hline 6500 & -243 & 136 & -107 \\
\hline 6600 & -343 & 136 & -207 \\
\hline 6700 & -443 & 136 & -307 \\
\hline 6800 & -543 & 136 & -407 \\
\hline 6900 & -643 & 136 & -507 \\
\hline 7000 & -743 & 136 & -607 \\
\hline & & & \\
\hline & & 136 & -136 \\
\hline
\end{tabular}




\section{Market Participants of Derivatives}

There are broadly three types of participants in the derivatives market - hedgers, traders (also called speculators) and arbitrageurs. An individual may play different roles in different market circumstances.

\section{Hedgers}

They face risk associated with the prices of underlying assets and use derivatives to reduce their risk. Corporations, investing institutions and banks all use derivative products to hedge or reduce their exposures to market variables such as interest rates, share values, bond prices, currency exchange rates and commodity prices.

\section{Speculators/Traders}

They try to predict the future movements in prices of underlying assets and based on the view, take positions in derivative contracts. Derivatives are preferred over underlying asset for trading purpose, as they offer leverage, are less expensive (cost of transaction is generally lower than that of the underlying) and are faster to execute in size (high volumes market).

\section{Arbitrageurs}

Arbitrage is a deal that produces profit by exploiting a price difference in a product in two different markets. Arbitrage originates when a trader purchases an asset cheaply in one location and simultaneously arranges to sell it at a higher price in another location. Such opportunities are unlikely to persist for very long, since arbitrageurs would rush in to these transactions, thus closing the price gap at different locations.

\section{Information on trends in F\&O markets:-}

a) Positive trend: It gives information about the top gainers in the futures market.

b) Negative trend: It gives information about the top losers in the futures market.

c) Futures OI gainers: It lists those futures whose \% increase in Open Interest is among the highest on that day.

d) Futures OI losers: It lists those futures whose \% decrease in Open Interest is among the highest on that day.

e) Active Calls: Calls with high trading volumes on that particular day.

f) Active Puts: Puts with high trading volumes on that particular day.

g) Put/ Call ratio (PCR): It gives the information about the ratio of trading volume of put to call options.

\section{Conclusion:-}

Investing in options market is always coupled with a risk factor which may be low or high and has got no accurate predictions that would work out. Option straddle strategy is truly the favourite financial instrument of retail and institutional investors over the past few decades all over the world. Options trading allow investors with very small funds to gain suspiciously big profits with limited risk. Options trading are so powerful, it also extremely complex and dangerous if it is not handled carefully. Options traders need a very firm knowledge of the basics of options trading before even thinking of ways to make the money out of it. Hence, this study would give a broad outlook for the new investors to discover about the straddle options strategy. 